\title{
Impact of Corporate Governance on Corporate Cash Holding: Evidence from Non-Financial Firms in Pakistan
}

\author{
Raza Zia-ul-Hannan ${ }^{1}$ Ms. Nadia Asghar ${ }^{2}$ \\ ${ }^{1}$ (Management Sciences, Foundation University Institute of Engineering \& Management Sciences, Pakistan)
}

\begin{abstract}
In this paper the researcher tired to study that how corporate governance effects corporate cash holdings in non-financial firms in Pakistan. For this purpose the researcher on the basis of convenient sampling studied the 22 non financial companies listed on KSE-100 Index from the time period of 2005 to 2010. The researcher took the cash as dependent variable while cash flow, liquidity, leverage, bank debt, market book, size, variability, dividend and others are independent variables. The researcher applied the multiple regression model after checking the data Heterosadacity and with the help of common effect model in STATA SE 10, researcher concluded that the relation between the corporate governance as well as the cash holdings from non financial firms in Pakistan will be negative.
\end{abstract}

Keywords: Cash Holding, Heterosadacity, KSE-100 Index, Non Financial Companies,

\section{Introduction}

Why sufficient amount of cash and cash equivalents are required to be held by the firms? Many reasons have been given about firms that hold the cash and equivalents of cash. Due to cash there can be low financing costs for the firms. It could be the main reason that why the firms like to hold the cash. It can also result in negative because a problem or conflict can arise between shareholders and the managers just because the firms have large amount of cash. Managers may use cash for their own needs without caring of shareholders. In other words they may see their benefit and it may annoy the shareholder whose cash is being used. It has also been reported that firms that obtain more volatile earnings may have higher costing for external financing.

In this research paper researcher studied about the cash holdings of some non financial firms in Pakistan from the time period of 2005 to 2010. It is very important to note that the firms in Pakistan are not checked by financial institutions or board of companies in an efficient manner. Thus it will then result in providing manager the freedom to use his dictating attitude. This paper tells us about structure of firm and ownership hierarchy while focusing at the cash holdings. Researcher examined that how do the managers as well as executives or even non executive directors put an influence on the cash holdings. The managers may use their power in utilizing the cash of shareholders without providing any information that where the investment has been made or utilized. Managers may invest the cash of shareholders to their private investments. So the relationship between managers and cash holdings will be negative. There must be good laws for the manager's monitoring as well as for shareholder's rights. By this the number of conflicts can be avoided.

The endogeneity issue is important for many reasons. The variables such as leverage as well as market to book ratio can be affected by cash holdings or even it can have affect on the cash holdings. This can also be helpful in telling that relationship between cash holding and other variables have what sort of effect on cash holding. Opler (1999), suggested a model that tells about actual cash holdings of the firm to the target cash holdings. It was called as target adjustment model. He had a view that the firms have target cash level. Moreover, the managerial ownership has an important effect regarding corporate cash holdings firms in Pakistan that are non financial. Researcher may conclude that the link or relationship between cash holdings and managerial ownership can be non-monotonic. The previous studies results show that the cash holdings cannot be influenced by any board or controllers. This is because if families are ultimate controllers of the firm, they tend to hold much cash than that which firm will be having such as the financial institutions. As it has been discussed before that maximized control of shareholder on the cash flow has a negative affect on cash holdings. Results may come in this view that higher cash holdings could be with respect to lower levels of bank debt and leverage. Then in this paper researchers discussed the features of corporate governance in non financial firms in Pakistan. Then there comes how the data has been constructed for evidence. Then researcher looked at the results and draws conclusion about the particular situation.

\section{Objective of the Study:}

The objective of this study is to check how corporate governance effect corporate cash holdings in nonfinancial firms in Pakistan. The cash is taken as dependent variable while cash flow, liquidity, leverage, bank debt, market book, size, variability, dividend and others are independent variables. 


\section{Review of Literature}

Amy, Jan and Henri (2003), analyzed 11,000 companies of 45 countries and concluded that the companies require holding more cash (mostly in double) in the countries with poor shareholder's right protection. Such cash holding are because of manager's personal well being not of shareholder's well beings. Such cash holding are also due to the easy access to the funds thus leads to the agency problems, as funds are not optimally used for investment alternatives and shareholder wealth maximization. Manuel, David and Markus (2011), investigated 1875 firms from 46 emerging and developed countries in 2007 and concluded that more cash with firms that have poor level governance. Such firms may invest higher cash holdings to negative NPV projects. Such firms can profit from cash holdings if they maintain dividend payout ratios. Yuanto Kusnadi (2006), made a study on the mechanisms of corporate governance on firm level and the cash holding's relationships, and how the firm value is affected by them. The firms which have poor governance will have a negative incremental value associated with holding cash excessively. The recognitions of minority shareholders in such firms will be reflected by discounts that are linked with these firms. Nicolas Couderc made a use of firm level data that consisted of 4515 firms. These firms were located in countries like USA, Canada, Germany, France etc. By this he was able to make a study on determinants and also investigated the consequences possessed by corporate cash holdings. The time period was taken from 1989 to 2002. The model of Bivariate Probit was implemented inorder to notice that there is a jointly relationship between cash balancing level and the firm's future performances. The firm performance may become poor due to its holding of cash excessively. Benjamin and Yuanjian concluded that how structure of corporate governance has effect on the corporate cash holdings. The listed companies of Nigeria were taken for this study. The regression model relating to Panel data was taken for such analysis and the results showed the corporate cash holdings are effect by corporate governance in a considerable manner. It has also been noticed that the Nigerian firms with respect to their cash and cash equivalents hold their assets in sizeable amount. Deqiu, Sifei, Jason, Hong (2005) highlights the research that how do the state rules put an effect on the rules as well as the policies of the firm. Many financial constraints can be avoided if there is a good government and by this there could be minimized cash hold by the firms. Jarrad, Sattar and William (2007) analyzed that firms with weaker corporate governance structures actually have smaller cash reserves. When distributing cash to shareholders, firms with weaker governance structures choose to repurchase instead of increasing dividends and thus avoiding future payout commitments. Firms with low shareholder rights and excess cash have lower profitability and valuations. Amy and Jan (2007) analyzed how corporate governance impacts firm value by comparing the value and use of cash holdings in poorly and well-governed firms. The governance has a substantial impact on value through its impact on cash which means $\$ 1.00$ of cash in a poorly governed firm is valued at only $\$ 0.42$ to $\$ 0.88$. Good governance approximately doubles the value. Berlin and Loeys (1988) analyzed that if a firm needs to finance an investment project, there must be alternative contracting arrangements with it. They also analyzed choice between loan contracts with indicators based covenants of the firm's financial health and loan contracts enforced by a monitoring specialist. It is important to note that specialist can be financial intermediary. Choice of the firm is shown to depend upon the firm's credit rating, the loss from premature liquidation of the firm's project, and the cost of monitoring. Baskin (1987) analyzed that there are material effects from product market competition. The liquid assets play an important role to signal commitment to retaliate against market will and to enable firms to rapidly find out new opportunities. The firms having high degree of valuations can hold large number of assets that can be liquidated. Black and Coffee (1994) analyzed that legal restrictions and path dependence plays an important role in country's corporate governance and finances. The U.K follows same pattern regarding institutional investors as U.S but has much looser regulation of these investors. They would often like to sell their shares rather than going for a change in management structure or strategy of the firm. They have a fear that their active nature may benefit their institutional rivals and this would limit their desire to participate in corporate governance. Arellano and Bond (1991) analyzed that there are some tests which plays an important role in the judging of a dynamic model that comes out from panel data and for it there must be some methods but these should be generalized regarding moments. And by making usage of data whether it is real or even generated one, it helps in identifying these procedures through its practical performances. This may exploit all the linear moment restrictions that may start when it is assumed that the correlation which is serial in nature will not be present among errors of the equation that may be having individual effects etc. They however, suggested generalized method of moments based serial correlation test. Then it was compared with Sargan tests of overidentifying restrictions and Hausman specification tests. Faccio and Lang (2002) analyzed 5,232 corporations and their ownership and control in 13 Western European countries. Widely held firms are $36.93 \%$ and family controlled firms are $44.29 \%$. It is important for financial and large firms to be widely held, while non-financial as well as small firms are more likely to be family controlled. It has been also judged that there could be significant discrepancies or differences between ownership and control in only a few countries. On the basis of the above mentioned literature review the researcher has studied the impact of corporate cash holding by investigating the non-financial companies listed in KSE-100 Index. 


\section{Methodology}

Sample: A sample of 22 non financial firms that were listed on Karachi stock exchange (KSE-100index) was taken for this research paper. This research paper studies the impact of company specific factors and corporate governance indicators on firm's cash holdings. Due to limitations of time, resources and acute unavailability of data of corporate governance, researcher restricted his samples to 22 companies. However, care was taken to include companies that represent all sectors of KSE-100index and that were present on the index during sample period (2005-2010).

Data Collection: As to study different independent and dependent variables, the balance sheet analysis owned by State Bank of Pakistan was being considered. This analysis was taken from 2006 to 2010. However figures for year 2005 were also taken in the study to calculate the lag of different variables.

\section{Measurement}

Test: The test applied for it is common effect model in STATA SE 10, which is most useful as all data taken is from manufacturing firms.

Model : The regression model is as under:

Cash $_{i, t}=\alpha_{i, t}+\beta_{1}$ Cashflow $_{i, t}+\beta_{2}$ Lev $_{i, t}+\beta_{3}$ mbr $_{i, t}+\beta_{4}$ size $_{i, t}+\beta_{5}$ Variability $_{i, t}+\beta_{6}$ man $_{i, t}+\beta_{7} e x_{i, t}+\beta_{8}$ nonex $_{i, t}+\beta_{9}$ nedr $_{i, t}+\mu_{i, t}$

Where:

lev $=$ leverage, Size $=$ size of the firm, ex $=$ Executives Directors, Nonex $=$ Non executive directors, man $=$ How much shares are hold by the family (spouse $\&$ children) and the executives themselves, nedr $=$ Ration of non executive directors i.e. Non executive / Total no. of director.

Variable Interpretation/ Procedure: Where, "Cashflow" is the sum of earnings before interest, tax and depreciation divided by total assets minus cash. "Lev" is the ratio of total debt to total assets minus cash. The "mbr"is the ratio of book value of total assets minus the book value of equity plus the market value of equity to book value of assets. The "size" is the natural log of total assets according to prices from 2005 to 2010 . The "variability" can be defined as the standard deviation taken of cash flow to the average taken of total assets. The "man" can be defined as shares owned by company's directors in percentage form. The "ex" stands for the total executive directors. The "nonex" stands for the total non-executive directors. The "nedr" tell us about the total non-executive directors divided by total directors whether executive or non executive both comes in this category. Moreover, the cash holding plays an important part and is measured by cash and cash equivalents divided by total assets minus cash.

\section{Results and Discussions:}

Hettest: In order to detect outliers in our data researcher conducted Bausch/Phagan test for heterosadacity under the following hypothesis:

$\mathrm{H}_{\mathrm{o}}=$ Constant variance if researcher get the "P" value of 0.05 or less.

This means that researcher rejects $\mathrm{H}_{\mathrm{o}}$ and confirms that the data is heterosadastic. As heterosadasity is detected, researcher conducted "Common Effect Model" with Rohbust Standard Errors. Hettest identifies that "P" values are less than 0.05 which tells that data is heterosadastic and "Common Effect Model" will be conducted with Rohbust Standard Errors.

HETTEST

Table-1

. hettest
Breusch-Pagan, Cook-We1sberg test for heteroskedasticity
Ho: Constant vartance
Variables: fitted values of eh
chiz(1)
Prob ch12 - $>0.0000$

$\operatorname{Lev}(-2.01)$ and it is negative significant, Non $\operatorname{Ex}(-2.34)$ and it is also negative significant. Cashflow (2.50) which is positive significant, Variability(2.54) which is also positive significant as shown in table-3. All others whether positive or negative are insignificant which includes $\operatorname{Mbr}(-1.19), \operatorname{Ex}(-1.50)$, Size(0.51), Man(1.62), Nedr $(0.30)$ as shown in table-3. With the help of 9 variables, the corporate governance was measured and 5 out of 9 were positive and 4 were negative. Researcher concluded that there is negative relationship between corporate governance and cash holdings of non financial firms in Pakistan. It is negative. 
Table-2

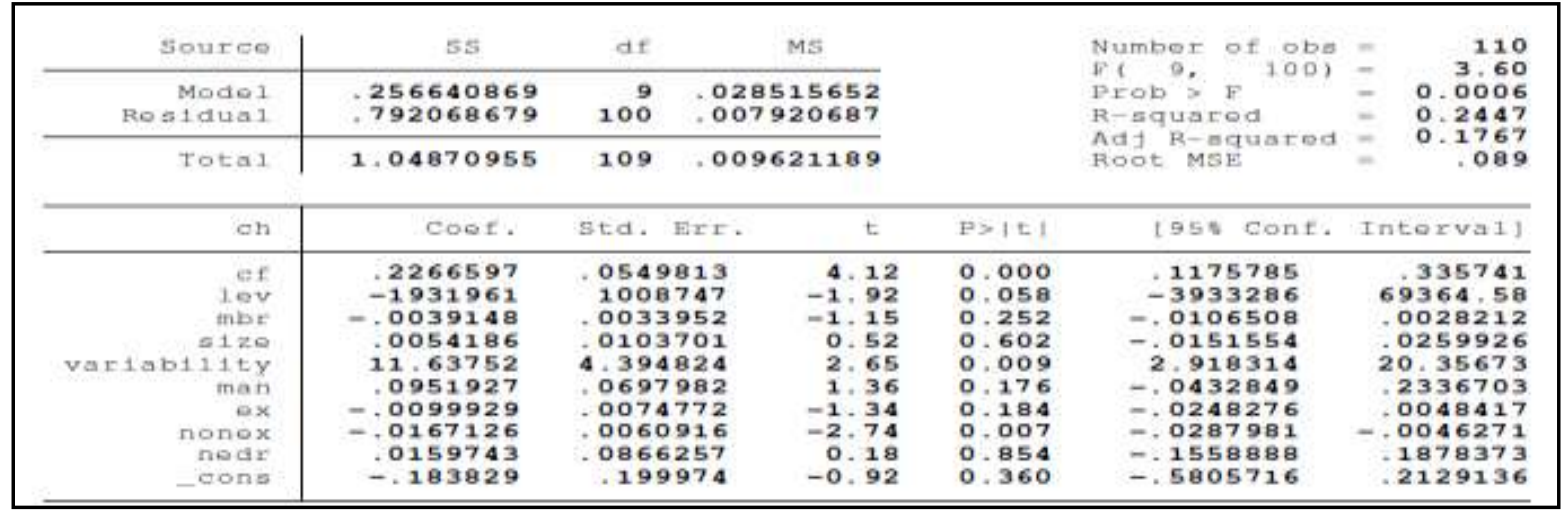

Table-3

\begin{tabular}{|c|c|c|c|c|c|c|}
\hline \multicolumn{5}{|c|}{ Linoar regrennion } & 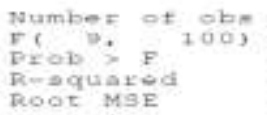 & $\begin{array}{l}=\quad 310 \\
=\quad 0.0003 \\
=\quad 0.2447 \\
=\quad 089\end{array}$ \\
\hline $\mathrm{eh}$ & coes. & $\begin{array}{l}\text { Robumt } \\
\text { SEA. ExF. }\end{array}$ & $=$ & $D>1=1$ & toss cont. & Intervali \\
\hline 0.7 & 2266597 & 090756 & 250 & 0.014 & 0466025 & 406717 \\
\hline $10 \mathrm{~V}$ & -1931961 & 961877,1 & & 0.047 & -3840297 & -23623.75 \\
\hline$m b x$ & -.0039148 & .0033036 & -1.19 & 0.239 & -.010469 & .0026394 \\
\hline$=1=0$ & .0054186 & .0107229 & 0.51 & 0.614 & -.0158554 & .0266926 \\
\hline$V A=L A b I I+E Y$ & 11.63752 & 4.584992 & 2.54 & 0.013 & 2.541026 & 20.73401 \\
\hline $\begin{array}{r}-10 \\
\operatorname{man}\end{array}$ & 0951927 & 0586788 & 1.62 & 0,108 & -0212244 & 2116097 \\
\hline $0 x$ & -0099929 & 0066457 & -1.50 & 0.136 & -0231779 & 003192 \\
\hline nonex & -0167126 & 0071352 & -2.34 & 0.021 & -0308687 & -0025565 \\
\hline nedx & 0159745 & OS4091a & 0.30 & 0.760 & $=0913424$ & 1232909 \\
\hline -eona & -.183829 & .2053937 & -0.90 & 0.373 & -.5913242 & 2236662 \\
\hline
\end{tabular}

\section{Conclusion}

In this study it has been seen that cash flow and variability or volatility are positive significant variables while leverage and non executive directors are negative significant variables. All others that include market to book ratio, size, man (shareholding by shareholders and their spouses and children), executive directors, non executive divided by total number of directors are insignificant variables. The results clearly show that non executive directors and leverage have an inverse relation with cash holding and the presence of non executive directors reduces company's need for large cash holdings. The result is in accordance with the literature which indicates that adherence to corporate governance reduces information symmetry and thus firms can get external finances easily. This enables firm to hold less cash and establish trust among the stakeholders. If there is more leverage it will result in less cash holding because if more leverage, it will cause debt servicing to rise and the cash holding will be affected negatively. The danger will rise because people will hold more cash due to precautionary measures. If cash flow will rise it will have a direct relation with cash holding which will rise because the amount of capital will then increase which causes cash holding to rise also. Same is the case with variability as it will also be directly related to cash holding.

\section{References}

[1] Amy and Jan (2007). "Corporate governance and the value of cash holdings.US

[2] Amy, Jan and Henri (2003). "International Corporate Governance and Corporate Cash holding" Journal and Financial and Quantitative Analysis, 38 (2003), 111- 133.

[3] Arellano M., Bond S., 1991. Some tests of specification for panel data: Monte Carlo evidence and an application to employment equations. The Review of Economics Studies 58, 277-297.

[4] Baskin J., 1987. Corporate liquidity in games of monopoly power. Review of Economics and Statistics 69, 312-319.

[5] Benjamin and Yuanjian "The Effect of Corporate Governance Structure on Corporate Cash Holdings: An Empirical Analysis of Nigerian Listed Firms.”

[6] Berlin M., Loeys J., 1988. Bond covenants and delegated monitoring. Journal of Finance 43, 397-412.

[7] Black B.S., Coffee J.C., 1994. Hail Britannia, Institutional investor behaviour under limited regulation. Michigan Law Review 92, 1997-2087.

[8] Deqiu, Sifei, Jason, Hong (2005). "The Effects of Government Quality on Corporate Cash Holdings."

[9] Faccio M., Lang H.P., 2002. The ultimate ownership of western European corporations. Journal of Financial Economics 65, 365395.

[10] Jarrad, Sattar and William (2007). "Corporate governance and firm cash holdings in the US."

[11] Manuel, David and Markus (2011). "Cash Holdings and Corporate Governance Around the World."

[12] Nicolas Couderc "Corporate cash holdings: financial determinants and consequences."

[13] Yuanto Kusnadi (2006). "Corporate Governance Mechanisms and Corporate Cash Holdings." 